\title{
Development and Validation of a New
} Stability Indicating Reversed-phase High-Performance Liquid Chromatography Method for the Simultaneous Estimation of Tegafur and Uracil in Capsule Dosage Form

\section{Sreenivasa Charan Archakam ${ }^{1}$, Sridhar Chenchugari², Chandrasekhar Kothapalli Banoth ${ }^{3}$}

\author{
${ }^{1}$ Department of Pharmaceutical Sciences, Jawaharlal Nehru Technological \\ University, Anantapuramu, Andhra Pradesh, India, ${ }^{2}$ Department of Pharmaceutical Analysis, Sri Padmavathi \\ School of Pharmacy, Tirupati, Andhra Pradesh, India, ${ }^{3}$ Department of Chemistry, Jawaharlal Nehru \\ Technological University, Anantapuramu, Andhra Pradesh, India
}

\section{Abstract}

Aim: The aim of this study is to develop a new stability indicating reversed-phase high-performance liquid chromatography (RP-HPLC) method for the simultaneous estimation of Tegafur (TEG) and Uracil (URA) in capsule dosage form. Materials and Methods: Chromatography was carried out on a C18 Phenomenex column (250 mm $\times$ $4.6 \mathrm{~mm}$ i.d., $5 \mu \mathrm{m}$ particle size) with an isocratic mobile phase composed of acetate buffer ( $\mathrm{pH} \mathrm{4}$ ) and methanol in the proportion of $70: 30(\mathrm{v} / \mathrm{v})$. The compounds were eluted at a steady flow rate of $1.0 \mathrm{~mL} / \mathrm{min}$ with a total run time of $10 \mathrm{~min}$. The detection was carried out by ultraviolet-detector at $280 \mathrm{~nm}$. The developed method was validated as per the ICH guidelines, and stability studies were performed. Results and Discussion: TEG retention time was about $5.2 \mathrm{~min}$, and URA was $2.9 \mathrm{~min}$. A calibration curve was obtained in the range of $25-125 \mu \mathrm{g} / \mathrm{mL}$ for TEG and $20-100 \mu \mathrm{g} / \mathrm{mL}$ for URA. Specificity experiments revealed the absence of interference from excipients. The mean assay for TEG was found to be $101.4 \%(\mathrm{w} / \mathrm{w})$ and for URA was $102.8 \%(\mathrm{w} / \mathrm{w})$. The method was also evaluated for robustness and ruggedness, and the results obtained were satisfactory. Forced degradation studies were performed for TEG and URA in acidic and alkaline, thermal, and oxidative conditions, and no substantial degradation was observed in all the conditions. Conclusion: It is concluded that the developed stability indicating RP-HPLC method was specific, precise, accurate, sensitive, and robust for the simultaneous estimation of TEG and URA in capsules.

Key words: Reversed-phase high-performance liquid chromatography, stability indicating assay, Tegafur, Uracil, validation

\section{INTRODUCTION}

$\mathrm{T}$ legafur (TEG) [Figure 1], a prodrug to fluorouracil, is used in combination with uracil (URA) [Figure 2] for the treatment of malignant growth of colon, stomach cancer, bowel cancer, and several other precancerous and cancerous growth conditions ${ }^{[1]}$ TEG is known to be a potential thymidylate synthase inhibitor. The URA causes higher amounts of 5-Fluorouracil to stay inside the cells and kill them. An extensive literature review revealed that no stability indicating analytical method was reported for the simultaneous estimation of TEG and URA. However, analytical methods for individual drugs and the selected drugs with other drug combinations were reported. Most of the reported methods were pharmacokinetic and bioanalytical methods which were employed in clinical

\author{
Address for correspondence: \\ Sreenivasa Charan Archakam, Research Scholar, \\ Department of Pharmaceutical Sciences, Jawaharlal \\ Nehru Technological University Anantapur, \\ Anantapuramu - 515 002, Andhra Pradesh, India. \\ Phone: +91-9490844432. \\ E-mail: charan4ma@gmail.com
}

Received: $17-07-2018$

Revised: 09-08-2018

Accepted: 16-08-2018 
trials of drug discovery. ${ }^{[2-15]}$ Thus, there is a scope for the development of a new stability indicating analytical method for the simultaneous estimation of TEG and URA and validate the developed method as per ICH guidelines. Forced degradation studies were carried to study the effect of various environments on the stability of the drugs.

\section{MATERIALS AND METHODS}

\section{Chemicals and reagents}

TEG and URA were purchased from TCI Chemicals Pvt. Ltd., Japan. TEG and URA capsules were available in the market as LUPORAL Capsules (LUPIN Ltd., India). All other AR grade chemicals and high-performance liquid chromatography (HPLC) grade solvents were purchased from Merck Pvt. Ltd., Mumbai.

\section{Equipment}

The chromatography was performed on Shimadzu Prominence LC system with LC-20AT pump, rheodyne injector, and

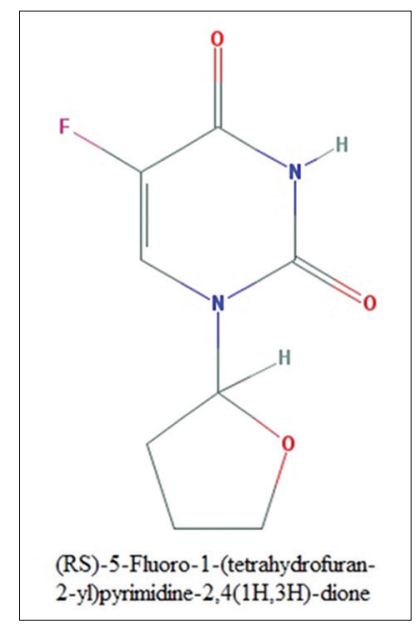

Figure 1: Chemical structure of tegafur

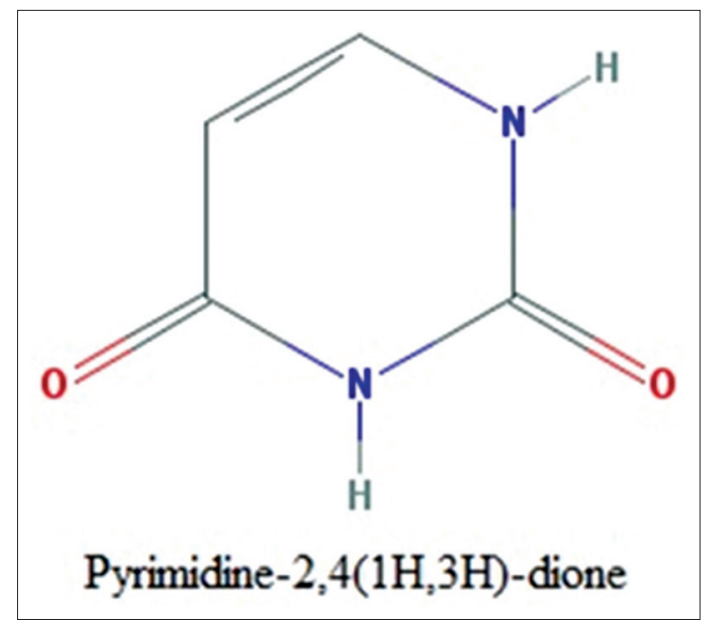

Figure 2: Chemical structure of uracil
SPD-20A ultraviolet (UV)-visible detector. The data handling system used was Lab solutions. Calibrated analytical balance (Shimadzu-AY220) and pH meter (Digisun) was also used in the study.

\section{Chromatographic separation conditions}

Chromatography was carried out on a C18 Phenomenex column $(250 \mathrm{~mm} \times 4.6 \mathrm{~mm}$ i.d., $5 \mu \mathrm{m}$ particle size $)$ with an isocratic mobile phase composed of acetate buffer ( $\mathrm{pH} 4$ ) and methanol in the proportion of 70:30 (v/v), with a steady flow rate of $1.0 \mathrm{~mL} / \mathrm{min}$ with a run time of $10 \mathrm{~min}$. The detection was carried out by UV-detector at $280 \mathrm{~nm}$. The temperature conditions were maintained at ambient conditions.

\section{Preparation of stock solutions of TEG and URA}

Stock solutions of TEG and URA were prepared by transferring $25 \mathrm{mg}$ individually into $25 \mathrm{~mL}$ of volumetric flasks and dissolving in $0.1 \mathrm{~N}$ sodium hydroxide. Finally, volume was made up to the mark with $0.1 \mathrm{~N}$ sodium hydroxide to give a solution containing $1000 \mu \mathrm{g} / \mathrm{mL}$.

\section{Method validation}

For linearity, the concentration range $25-125 \mu \mathrm{g} / \mathrm{mL}$ was established for TEG and the concentration range 20-100 $\mu \mathrm{g} /$ $\mathrm{mL}$ was established for URA. $20 \mu \mathrm{L}$ of each of the prepared stock solutions was injected into the chromatographic system connected to a column, and the average peak area in each of the cases was noted. By plotting concentrations on $\mathrm{X}$-axis and corresponding peak area on Y-axis, the linearity was determined. The precision of the method was demonstrated through two parameters which are injection reproducibility (system precision) and the method precision. Accuracy was performed in three levels of concentration, i.e. $50 \%, 100 \%$, and $150 \%$ of label claim by standard addition technique. The robustness of a method is evaluated by varying method parameters such as flow rate $( \pm 0.2 \mathrm{~mL} / \mathrm{min})$, wavelength $( \pm 2 \mathrm{~nm})$, analyst-to-analyst variation, and determining the effect (if any) on the results of the method.

\section{Assay of capsule dosage form}

20 capsules were taken and accurately weighed $0.174 \mathrm{~g}$ of fine powder of capsule and transferred into a $50 \mathrm{~mL}$ clean, dry volumetric flask, then add $0.1 \mathrm{~N}$ sodium hydroxide and kept for sonication for $10 \mathrm{~min}$ to dissolve, and then make up the volume with diluent and then filtered through $0.45 \mu$ membrane filter. The test solution was prepared to get a final concentration of $25 \mu \mathrm{g} / \mathrm{mL}$ (TEG) and 56 $\mu \mathrm{g} / \mathrm{mL}$ (URA). Triplicate solutions of prepared solutions of $20 \mu \mathrm{L}$ were injected into the reversed-phase HPLC (RP-HPLC) system, and the chromatographic parameters were analyzed. 


\section{Forced degradation studies}

Forced degradation studies were performed for TEG and URA in acidic hydrolysis, basic hydrolysis, thermal, and oxidative conditions. Hydrolysis under acidic conditions was performed by exposing the drug solution to $0.1 \mathrm{~N} \mathrm{HCl}$ at $60^{\circ} \mathrm{C}$ for $6 \mathrm{~h}$ and then cooled, neutralized with $0.1 \mathrm{~N} \mathrm{NaOH}$, and the volume was made up to $10 \mathrm{~mL}$ with diluent and filtered. Hydrolysis under alkaline conditions was performed by exposing the drug solution to $0.1 \mathrm{~N} \mathrm{NaOH}$ at $60^{\circ} \mathrm{C}$ for $6 \mathrm{~h}$ and then cooled, neutralized with $0.1 \mathrm{~N} \mathrm{HCl}$, and the volume was made up to $10 \mathrm{~mL}$ with diluent and filtered. Thermal degradation was carried by exposing the drug solution to $60^{\circ} \mathrm{C}$ for $24 \mathrm{~h}$ and then cooled, and volume was made up to $10 \mathrm{~mL}$ with diluent and filtered. Oxidative stress was studied by exposing the drug solution to $0.3 \% \mathrm{v} / \mathrm{v} \mathrm{H}_{2} \mathrm{O}_{2}$ for

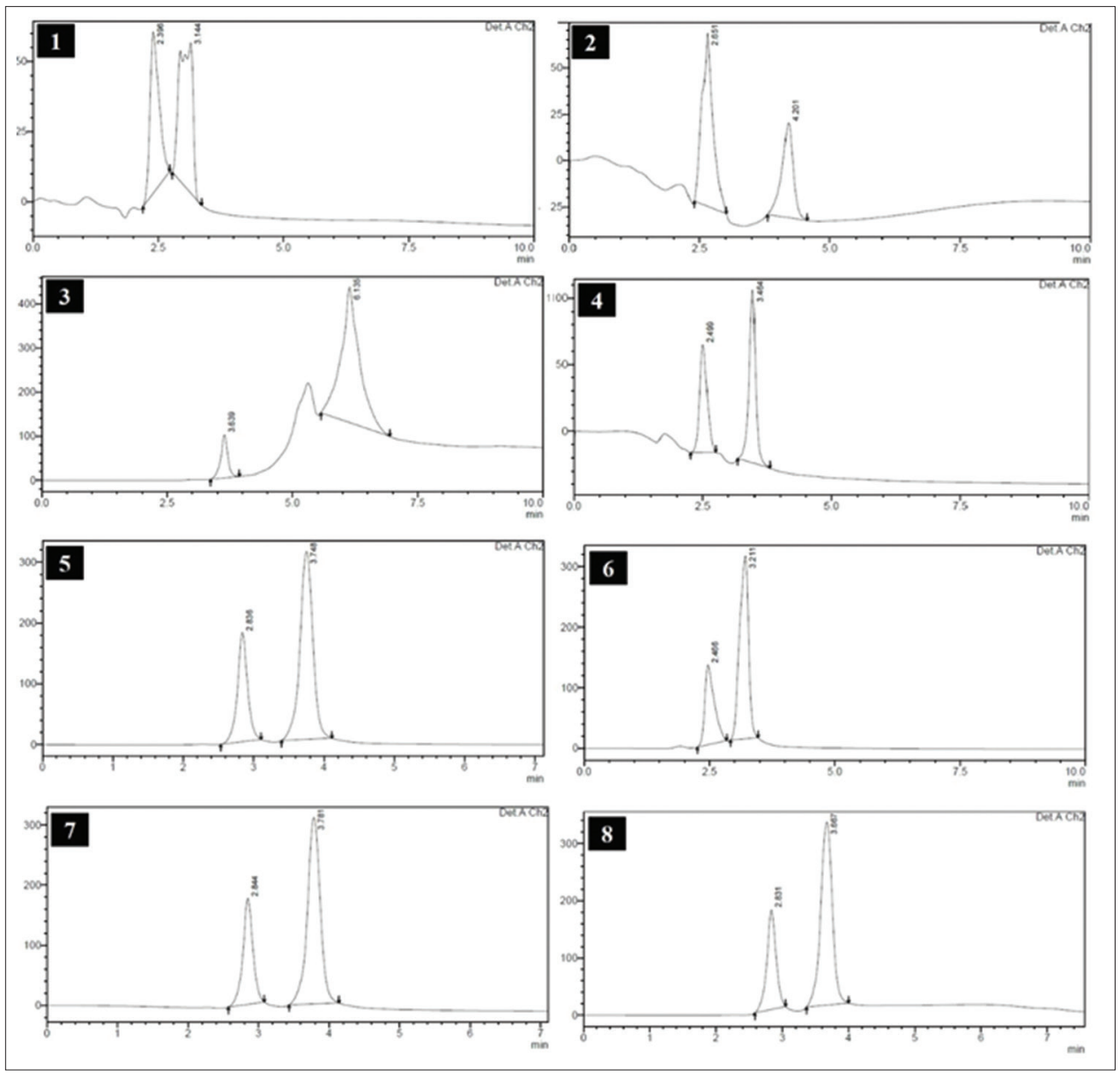

Figure 3: (1-8) Trial chromatograms during method development

\begin{tabular}{|c|c|c|}
\hline Trials & Mobile phase & Observations \\
\hline 1. & $\begin{array}{l}\text { Phosphate buffer } \mathrm{pH}-6.8 \text { : } \\
\text { Acetonitrile (50:50) }\end{array}$ & $\begin{array}{l}\text { No complete separation of peaks. Less } \\
\text { theoretical plate count }\end{array}$ \\
\hline 2. & $\begin{array}{l}\text { Phosphate buffer } \mathrm{pH}-6.8 \text { : } \\
\text { Methanol }(70: 30)\end{array}$ & $\begin{array}{l}\text { Baseline disturbances. Less theoretical plate } \\
\text { count }\end{array}$ \\
\hline 3. & $\begin{array}{l}\text { Phosphate buffer } \mathrm{pH}-5 \text { : } \\
\text { Acetonitrile (50:50) }\end{array}$ & $\begin{array}{l}\text { Baseline disturbances. Interference of ghost } \\
\text { peaks }\end{array}$ \\
\hline 4. & $\begin{array}{l}\text { Phosphate buffer } \mathrm{pH}-5 \text { : } \\
\text { Acetonitrile }(60: 40)\end{array}$ & Low resolution. Baseline disturbances \\
\hline 5. & Acetate buffer $\mathrm{pH}-4$ : Methanol (50:50) & Low resolution and less theoretical plate count \\
\hline 6. & Acetate buffer $\mathrm{pH}$ - 4: Acetonitrile (50:50) & Low resolution and less theoretical plate count \\
\hline 7. & Acetate buffer $\mathrm{pH}$ - 4: Methanol $(55: 45)$ & Low resolution and less theoretical plate count \\
\hline 8. & Acetate buffer $\mathrm{pH}$ - 4: Methanol (60:40) & Less theoretical plate count \\
\hline
\end{tabular}

HPLC: High-performance liquid chromatography 
$15 \mathrm{~min}$. All the respective solutions were injected $(20 \mu \mathrm{L})$ into HPLC system, and their chromatographic parameters were analyzed.

\section{RESULTS AND DISCUSSION}

\section{RP-HPLC method development and optimization}

The initial conditions for the chromatography were designed based on the nature of sample, literature, availability, and cost parameters. Several trials were performed by altering mobile phase and keeping the column, flow rate, and other conditions without changing. The result chromatograms [Figure 3] of the trials are presented in Table 1. The final optimized conditions for the separation were optimized, and the conditions are shown in Table 2.

A simple RP-HPLC method was developed for the simultaneous estimation of TEG and URA using a C18 phenomenex column $(250 \mathrm{~mm} \times 4.6 \mathrm{~mm}$ i.d., $5 \mu \mathrm{m}$ particle size) with an isocratic mobile phase composed of acetate buffer $(\mathrm{pH} 4)$ and methanol in the proportion of 70:30 (v/v) with a steady flow rate of $1.0 \mathrm{~mL} / \mathrm{min}$ with a run time of $10 \mathrm{~min}$. The detection was carried out by UV-detector at $280 \mathrm{~nm}$. TEG retention time was about $5.2 \mathrm{~min}$ and URA was

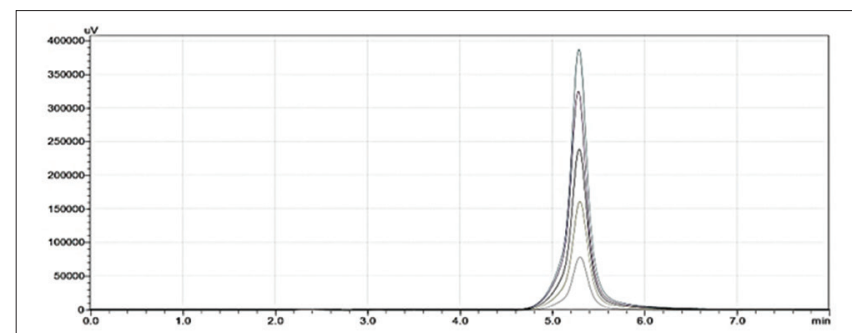

a
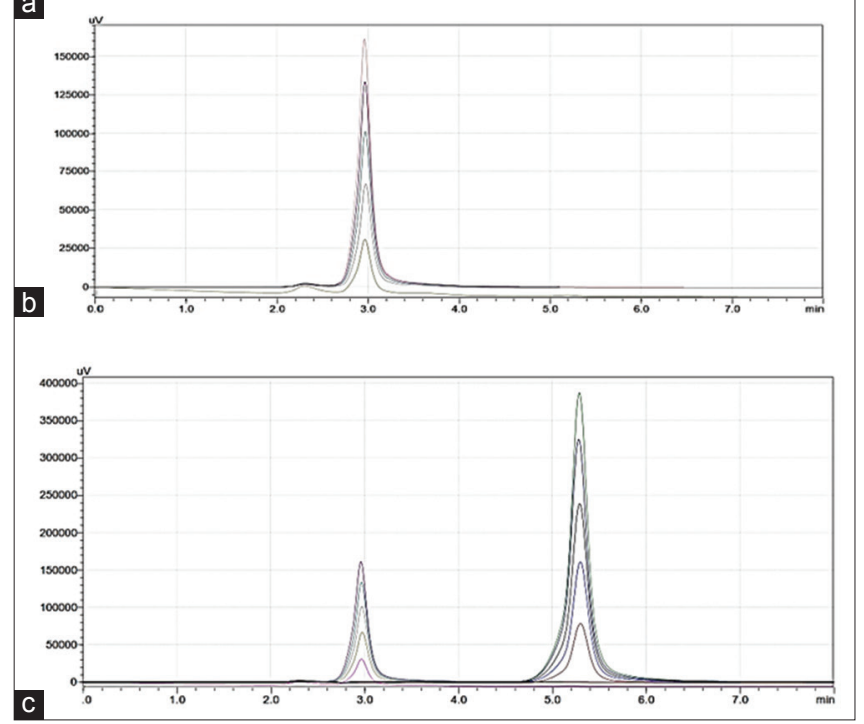

Figure 4: Optimized chromatograms: (a) Linearity chromatograms of tegafur (TEG) (b) linearity chromatograms of uracil (URA) (c) optimized method chromatograms for TEG and URA
2.9 min which was confirmed by injecting individual drug solutions under the same conditions.

\section{Method validation}

The developed method was validated as per the ICH guidelines ${ }^{[16,17]}$ for various parameters such as linearity, range, precision, accuracy, and robustness [Figure 4]. A calibration curve [Tables 3 and 4] was obtained in the range of 25-125 $\mu \mathrm{g} / \mathrm{mL}$ for TEG and $20-100 \mu \mathrm{g} / \mathrm{mL}$ for URA [Figures 5 and 6]. Both calibration curves showed a good correlation of $>0.999$. Specificity experiments revealed the absence of interference from excipients. The precision was done for

\section{Table 2 : Optimized chromatographic conditions}

\begin{tabular}{ll} 
Parameter & Optimized conditions \\
\hline Column & $\begin{array}{l}\text { Phenomenex C18 } 5 \mu(250 \\
\mathrm{mm} \times 4.6 \mathrm{~mm})\end{array}$ \\
Mobile phase & $\begin{array}{l}\text { Acetate buffer } \\
\mathrm{pH} 4-\text { methanol }(70: 30) ; \\
\text { isocratic conditions }\end{array}$ \\
& $1.0 \mathrm{~mL} / \mathrm{min}$ \\
Flow rate & $20 \mu \mathrm{L}$ \\
Injection volume & Ambient temperature \\
Temperature & UV-Visible detection at $280 \mathrm{~nm}$ \\
Detection wavelength & $10 \mathrm{~min}$ \\
Runtime & $5.294 \pm 0.011$ min \\
Retention time for & \\
TEG & $2.974 \pm 0.006$ min \\
Retention time for & \\
URA &
\end{tabular}

UV: Ultraviolet, TEG: Tegafur, URA: Uracil

\begin{tabular}{lc}
\multicolumn{2}{c}{ Table 3: Linearity data of TEF } \\
$\begin{array}{l}\text { Concentration } \\
(\mu \mathrm{g} / \mathrm{mL})\end{array}$ & $\begin{array}{c}\text { Peak area of } \\
\text { TEG }\end{array}$ \\
\hline 25 & 1070098 \\
50 & 2220290 \\
75 & 3358442 \\
100 & 4420979 \\
125 & 5382209 \\
\hline
\end{tabular}

TEG: Tegafur, URA: Uracil

\begin{tabular}{lc}
\multicolumn{2}{c}{ Table 4: Linearity data of URA } \\
$\begin{array}{l}\text { Concentration } \\
(\boldsymbol{\mu g} / \mathrm{mL})\end{array}$ & $\begin{array}{c}\text { Peak area of } \\
\text { URA }\end{array}$ \\
\hline 20 & 361052 \\
40 & 678334 \\
60 & 1047877 \\
80 & 1352974 \\
100 & 1666935
\end{tabular}

TEG: Tegafur, URA: Uracil 
both system [Table 5] and method [Table 6] precision. All the results were acceptable with $\%$ relative standard deviation values $<2$. Accuracy was performed based on percentage recovery studies [Table 7]. TEG showed a mean percentage recovery of $99.69 \%$ and URA showed mean percentage

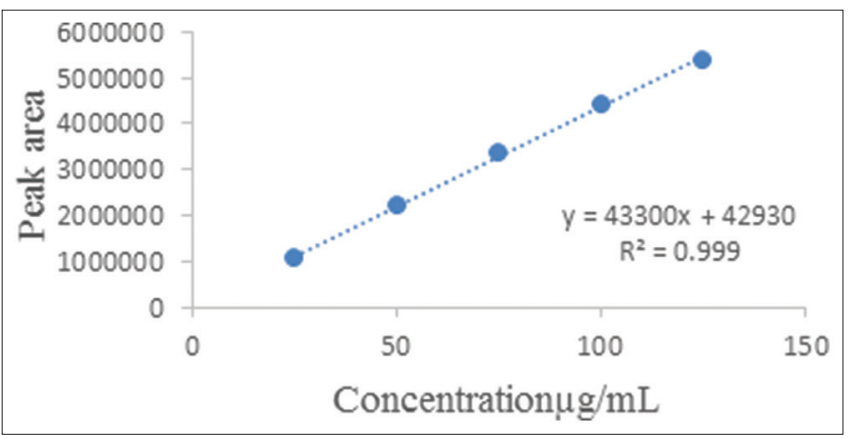

Figure 5: Linearity curve of tegafur

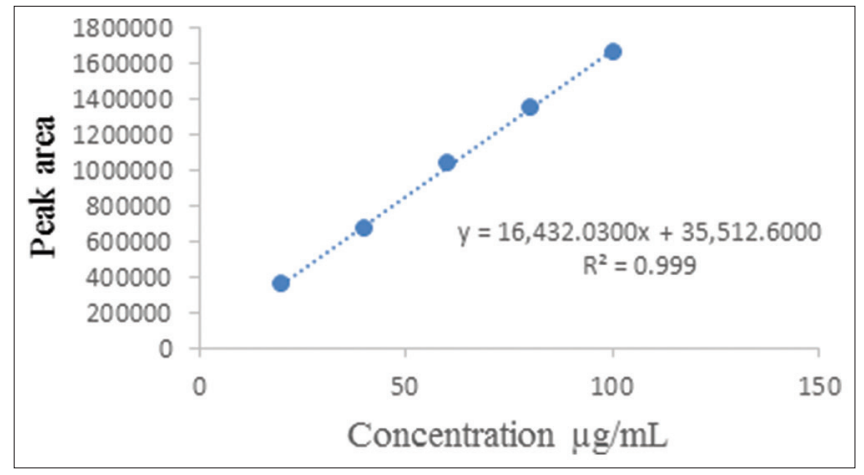

Figure 6: Linearity curve of uracil recovery of $100.82 \%$. The method was also evaluated for robustness and ruggedness, and the results obtained were satisfactory [Figure 7].

\section{ASSAY RESULTS}

The mean assay for TEG was found to be $101.41 \%(\mathrm{w} / \mathrm{w})$ and for URA was $102.82 \%(w / w)$ [Table 8 ].

\section{Forced degradation studies}

Forced degradation studies were performed for TEG and URA at various conditions such as acidic hydrolysis and basic hydrolysis, thermal, and oxidative conditions, and the percentage degradation values were calculated. All the chromatograms showed no considerable degradation of the drugs at various stress conditions.

\section{CONCLUSIONS}

The developed stability indicating RP-HPLC method was specific, precise, accurate, sensitive, and robust for the simultaneous estimation of TEG and URA in capsules. The proposed method can be used for the simultaneous analysis of the two drugs by various pharmaceutical laboratories and research institutions.

\section{Table 5: System precision data of TEG and URA}

\begin{tabular}{|c|c|c|c|c|}
\hline \multirow[t]{2}{*}{ Injection No. } & \multicolumn{2}{|c|}{ TEG } & \multicolumn{2}{|c|}{ URA } \\
\hline & Peak Area & $\begin{array}{l}\text { Retention } \\
\text { time (min) }\end{array}$ & Peak Area & $\begin{array}{l}\text { Retention } \\
\text { time (min) }\end{array}$ \\
\hline 1 & 1168809 & 5.297 & 970920 & 2.978 \\
\hline 2 & 1204278 & 5.306 & 1007132 & 2.983 \\
\hline 3 & 1169445 & 5.292 & 1002866 & 2.967 \\
\hline Mean $\pm S D$ & $1180844 \pm 20296.93$ & - & $993639.3 \pm 19790.8$ & - \\
\hline$\%$ RSD & 1.71 & - & 1.99 & - \\
\hline
\end{tabular}

RSD: Relative standard deviation, SD: Standard deviation, TEG: Tegafur, URA: Uracil

Table 6: Method Precision data of TEG and URA

\begin{tabular}{|c|c|c|c|c|}
\hline \multirow[t]{2}{*}{ Injection No. } & \multicolumn{2}{|c|}{ TEG } & \multicolumn{2}{|c|}{ URA } \\
\hline & Peak area & $\begin{array}{l}\text { Retention } \\
\text { time (min) }\end{array}$ & Peak area & $\begin{array}{l}\text { Retention } \\
\text { time (min) }\end{array}$ \\
\hline 1 & 950135 & 5.520 & 1003680 & 2.999 \\
\hline 2 & 951850 & 5.523 & 998350 & 3.002 \\
\hline 3 & 991848 & 5.525 & 998335 & 3.002 \\
\hline Mean \pm SD & $964611 \pm 23603.52$ & - & $1000122 \pm 3081.616$ & - \\
\hline$\%$ RSD & 0.269 & - & 0.308 & - \\
\hline
\end{tabular}

RSD: Relative standard deviation, SD: Standard deviation, TEG: Tegafur, URA: Uracil 


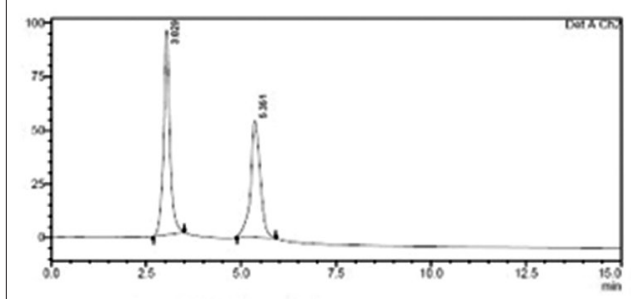

Acid Hydrolysis

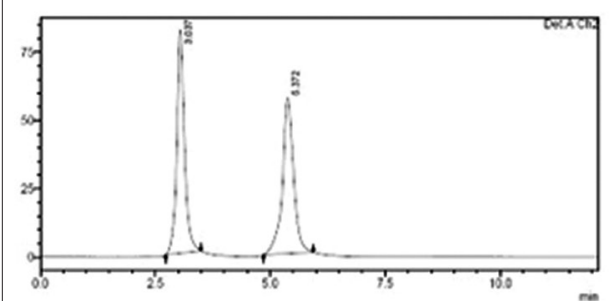

Oxidative

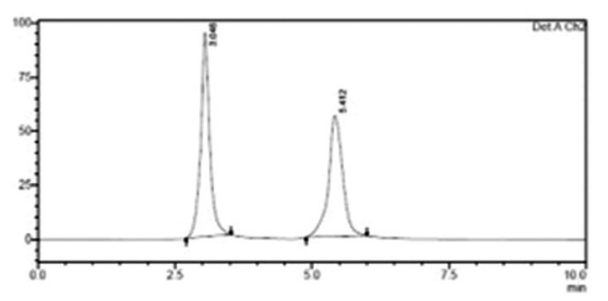

Basic Hydrolysis

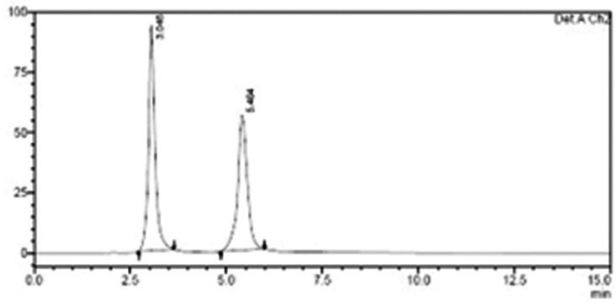

Thermal

Figure 7: Chromatograms of forced degradation studies

\begin{tabular}{|c|c|c|c|c|c|}
\hline \multicolumn{3}{|c|}{ TEG } & \multicolumn{3}{|c|}{ URA } \\
\hline $\begin{array}{l}\% \\
\text { Level }\end{array}$ & $\begin{array}{c}\text { Sample peak } \\
\text { area }\end{array}$ & $\begin{array}{c}\% \\
\text { recovery } \pm S D\end{array}$ & $\begin{array}{c}\% \\
\text { level }\end{array}$ & $\begin{array}{c}\text { Sample peak } \\
\text { area }\end{array}$ & $\begin{array}{c}\% \\
\text { recovery } \pm \text { SD }\end{array}$ \\
\hline 50 & 1599879 & $97.08 \pm 0.33$ & 50 & 1453739 & $102.46 \pm 0.50$ \\
\hline 100 & 2289678 & $104.0 \pm 0.5$ & 100 & 1795767 & $95.6 \pm 0.8$ \\
\hline 150 & 2648976 & $98.0 \pm 0.4$ & 150 & 2452195 & $104.4 \pm 0.65$ \\
\hline
\end{tabular}

SD: Standard deviation, TEG: Tegafur, URA: Uracil

\begin{tabular}{|c|c|c|}
\hline $\begin{array}{l}\text { Peak } \\
\text { areas }\end{array}$ & TEG & URA \\
\hline \% Assay & $101.41 \%(w / w)$ & $102.82 \%(w / w)$ \\
\hline
\end{tabular}

\section{ACKNOWLEDGMENT}

The authors would like to thank Dr. D. Ranganayakulu, Principal, and Smt. P. Sulochana, Correspondent, Sri Padmavathi Educational Institutions, Tiruchanoor, Tirupati, for providing research facilities to carry out this work.

\section{REFERENCES}

1. Etienne-Grimaldi M, François E, Cardot J, Renée N, Douillard J, Gamelin E. A clinical pharmacokinetic analysis of tegafur-uracil (UFT) plus leucovorin given in a new twice-daily oral administration schedule. Clin Pharmacokinet 2007;46:953-63.

2. Breda M, Barattè S. A review of analytical methods for the determination of 5-fluorouracil in biological matrices. Anal Bioanal Chem 2010;397:1191-201.
3. Maring JG, Schouten L, Greijdanus B, De Vries EG, Uges DR. A simple and sensitive fully validated HPLC-UV method for the determination of 5-fluorouracil and its metabolite 5, 6-dihydrofluorouracil in plasma. Ther Drug Monit 2005;27:25-30.

4. Alsarra IA, Alarifi MN. Validated liquid chromatographic determination of 5 -fluorouracil in human plasma. J Chromatogr B Analyt Technol Biomed Life Sci 2004;804:435-9.

5. Zufia L, Aldaz A, Castellanos C, Giraldez J. Determination of 5-fluorouracil and its prodrug tegafur in plasma and tissue by high-performance liquid chromatography in a single injection: Validation for application in clinical pharmacokinetic studies. Ther Drug Monit 2003;25:221-8.

6. Chu D, Gua J, Liu W, Fawcett JP, Dong Q. Sensitive liquid chromatographic assay for the simultaneous determination of 5-fluorouracil and its prodrug, tegafur, in beagle dog plasma. J Chromatogr B Analyt Technol Biomed Life Sci 2003;795:377-82.

7. Casale F, Canapaio R, Muntoni E, Serpe L, Zara GP, Della Pepa C, et al. Simultaneous HPLC determination of 5-fluorouracil and its metabolites in plasma of cancer patients. Biomed Chromatogr 2002;16:446-52.

8. Loos W, De Bruijn P, Van Zlen L, Verweij J, Nooter K, 
Stoter G, et al. Determination of 5-fluorouracil in microvolumes of human plasma by solvent extraction and high-performance liquid chromatography. J Chromatogr B Biomed Sci Appl 1999;735:293-7.

9. Tonano JS, Vermes A, Guchelaar HJ. Simultaneous determination of flucytosine and fluorouracil in human plasma by high performance liquid chromatography. Biomed Chromatogr 2001;15:89-94.

10. Escoriaza J, Aldaz A, Calvo E, Giraldez J. Simple and sensitive determination of 5-fluorouracil in plasma by high-performance liquid chromatography: Application to clinical pharmacokinetic studies. J Chromatogr B Biomed Sci Appl 1999;736:97-102.

11. Jung M, Berger G, Pohlen U, Pauser S, Reszka R, Buhr HJ. Simultaneous determination of 5-fluorouracil and its active metabolites in serum and tissue by highperformance liquid chromatography. J Chromatogr B Biomed Sci Appl 1997;702:193-202.

12. Gamelin E, Boisdron-Celle M, Turacant A, Larra F, Allain P, Robert J. Rapid and sensitive high-performance liquid chromatographic analysis of halogenopyrimidines in plasma. J Chromatogr B Biomed Sci Appl 1997;695:409-16.
13. Joulia JM, Pinguet F, Grosse PY, Astre C, Bressolle F. Determination of 5-fluorouracil and its main metabolites in plasma by high-performance liquid chromatography: Application to a pharmacokinetic study. J Chromatogr B Biomed Sci Appl 1997;692:427-35.

14. Wattanatorn W, McLeod HK, Cassidy J, Kendle KE. High-performance liquid chromatographic assay of 5-fluorouracil in human erythrocytes, plasma and whole blood. J Chromatogr B Biomed Sci Appl 1997;692:233-7.

15. Coe RA, Earl RA, Johnson TC, Lee JW. Determination of 5-fluorouracil in human plasma by a simple and sensitive reversed-phase HPLC method. J Pharm Biomed Anal 1996;14:1733-41.

16. ICH Harmonized Tripartite Guidelines. Validation of Analytical Procedures: Methodology (Q2B). Geneva: ICH Harmonized Tripartite Guidelines; 1996.

17. International Conference on Harmonization of Technical Requirement for the Registration of Pharmaceutical for Human Use: Validation of Analytical Procedures, Text and methodology- Q2(R1); 2005.

Source of Support: Nil. Conflict of Interest: None declared. 